\title{
Study of transverse deformation of porous alumina during uniaxial mechanical tests
}

\author{
A. D. KASHIN = Institute of Strength Physics and Materials Science SB RAS, \\ Tomsk, 634055 Russia - kash@ispms.ru \\ A. S. KULKOV - Institute of Strength Physics and Materials Science SB RAS, Tomsk, 634055 Russia \\ S. N. KULKOV - Institute of Strength Physics and Materials Science SB RAS, \\ Tomsk, 634055 Russia - kulkov@ms.tsc.ru \\ E. KUROVICS - Institute of Ceramics and Polymer Engineering, \\ University of Miskolc, Hungary - fememese@uni-miskolc.hu \\ L. A. GÖMZE - Institute of Ceramics and Polymer Engineering, \\ University of Miskolc, Hungary, IGREX Engineering Service Ltd - femgomze@uni-miskolc.hu \\ Érkezett: 2021. 06. 03. - Received: 03. 06. 2021. " https://doi.org/10.14382/epitoanyag-jsbcm.2021.21
}

\begin{abstract}
In this article presents the results of laboratory tests and analysis of the mechanical behavior of $\mathrm{Al}_{2} \mathrm{O}_{3}$-based samples during mechanical uniaxial compression testing. The samples with different porosities are obtained via different sintering temperatures. It has been shown that an increase of strength and, accordingly, decrease in porosity are significantly determined the changes of the Poisson's ratio under loading, and this change begins long before the appearance of the first internal microcracks in the internal parts of the material, i.e., the appearance of excess volume. These results clearly show the phenomenon of dilatancy, with a sharp increase of effective Poisson's ratio.

Keywords: $\mathrm{Al}_{2} \mathrm{O}_{3}$, porosity, dilatancy, compression testing, transverse strain, X-ray diffraction Kulcsszavak: $\mathrm{Al}_{2} \mathrm{O}_{3}$, porozitás, dilatáció, nyomószilárdság teszt, keresztirányú alakváltozás, röntgendiffrakció
\end{abstract}

\section{Introduction}

The analysis of the current state of ceramic materials researching shows that the main interest is represented by the studies of correlation between porosity and strength of ceramics. The main researches of $\mathrm{Al}_{2} \mathrm{O}_{3}$-based ceramic materials are carried out in the field of compression testing, structure analysis, X-ray diffraction etc. [1-7]. There is much less attention given to the research of the dilatancy phenomenon, based on the Poisson's ratio change of $\mathrm{Al}_{2} \mathrm{O}_{3}$ samples with different porosities obtained at different sintering temperatures.

Identification of unstable crack growth threshold (threshold of absolute dilatancy) can be done with a good level of precision, but identification of the onset crack initiation (threshold of relative dilatancy) is not easy, especially in porous materials [8-9]. In last years various authors have proposed different methods for crack initiation threshold identification [10-11], for example, the change in Poisson's ratio as an indicator for establishing crack initiation threshold.

The increase in the specific volume of the material during the dilatancy process corresponds to an increase in the effective Poisson's ratio. Formally, during measurements, it is possible to obtain an increase in this value to 1 or more, although, as is known, for continuous media, the maximum possible value of the Poisson's ratio (the ratio of the values of longitudinal and transverse relative deformations) can be not more than 0.5. Ceramic materials and rocks very often have residual porosity, so under the influence of stresses, compaction of the material can occur, and at the same time, due to the anisotropy
A. D. KASHIN

is working as research assistant under supervision of Prof. Kulkov at Institute of Strength Physics and Materials Science of the Russian Academy of Sciences in Tomsk.

Aleksey S KULKOV is physicist and has got PhD scientific degree at Tomsk State University in Russian Federation. At present he is working as research fellow at Institute of Strength Physics and Materials Science of the Russian Academy of Sciences in Tomsk.

Sergei N. KULKOV is professor at the Tomsk State University and head of Department of Ceramics in the Institute of Strength Physics and Materials Science of the Russian Academy of Science since 1989. His research works are represented in 5 books, more than 150 articles, 18 patents and many International Symposiums and Conferences. At present he is head of department "Theory of Strength and Mechanic of Solids", member of "The American Ceramic Society" of "The APMI International" and the DYM AT Society (France).

Emese KUROVICS is graduated in the University of Miskolc, Institute of Ceramics and Polymer Engineering as a material engineer, where she actually continues her study as PhD student under supervision of Prof. L. A. Gömze.

László A. GÖMZE is establisher and professor of the Department of Ceramics and Silicate Engineering in the University of Miskolc, Hungary. He is author or coauthor of 2 patents, 6 books and more than 300 scientific papers. Recently, he is the chair of the International Organization Board of ic-cmtp6 the $6^{\text {th }}$ International Conference on Competitive Materials and Technological Processes and ec-siliconf2 the $2^{\text {nd }}$ European Conference on Silicon and Silica Based Materials.

of loading, the initial value of the Poisson's ratio can be very small. At high stresses, compaction is replaced by dilatancy with an increase in the effective Poisson's ratio and subsequent fracture.

Apparently, the appearance of microcracks in such materials occurs at stresses below the elastic limit, but in general, the loading diagram corresponds to an elastic-plastic body.

Literature data shows that when loading, for example, soil, there is a non-linearity not only in the volume deformability (compression), but also in shear deformation, which are caused not only by tangential, but also by normal stresses, with the appearance of the dilatancy effect, which in the case of crushing, i.e., micro-destruction, leads to the need to take into account other effects - hardening, deformation rate, etc.

However, cumulative studies of $\mathrm{Al}_{2} \mathrm{O}_{3}$ samples obtained at different sintering temperatures and comprehensively investigated by these methods with the data capturing of transverse deformation in situ, have not been properly carried out yet. The correlation between Poisson's ratio change and transverse strain has also not been thoroughly researched in this class of materials. It is known that $\mathrm{Al}_{2} \mathrm{O}_{3}$ exhibits a phenomenon of dilatancy under load, but the effect of this phenomenon has not been properly explored yet. 
Thus, the aim of this paper is to study the internal structure of alumina samples with different porosities and their mechanical behavior under uniaxial loading tests.

\section{Materials and methods}

Ceramic samples in the form of rectangular parallelepipeds with the initial dimensions $36 \times 7 \times 6 \mathrm{~mm}$ were obtained by pressing commercially pure $\mathrm{Al}_{2} \mathrm{O}_{3}$ powder. It was mechanically processed in a ball mill in the span of 70 hours, which resulted in producing fine particles with a homogeneous size distribution.

The samples were sintered in the Nabertherm LHT 02/17 high-temperature muffle furnace. The various batches of samples were first slowly heated (within 6 hours) to the set temperatures of $1350^{\circ} \mathrm{C}, 1450^{\circ} \mathrm{C}, 1550^{\circ} \mathrm{C}$ and $1650^{\circ} \mathrm{C}$. Then they were held for 1 hour and then slowly cooled down to $40^{\circ} \mathrm{C}$. This was done with the purpose of obtaining $\mathrm{Al}_{2} \mathrm{O}_{3}$ samples with different porosities ranging in between 15 to $50 \%$. Sintered $\mathrm{Al}_{2} \mathrm{O}_{3}$ samples were mechanically treated using the Struers Secotom-10 precision cutting machine to achieve their plane-parallel flatness. After the three-point bending tests, the samples were cut to $15 \mathrm{~mm}$ in height with the $7 \times 6 \mathrm{~mm}$ cross section for compression testing and simultaneous measuring of transverse strain.

Both bending and compression tests were carried out using the Instron-1185 universal testing machine for determining flexural and compressive strength, technical elastic moduli and longitudinal strain values of the $\mathrm{Al}_{2} \mathrm{O}_{3}$ samples. Transverse strain was measured mechanically using a strain gauge device multiturn measuring head - with an accuracy of $1 \mu \mathrm{m}$.

The structure parameters and detailed microstructural study of the samples were investigated using the $\mathrm{X}$-ray diffractometer with filtered $\mathrm{CuK}_{\alpha}$ radiation. For the analysis of the polished sample surface the Vega 3 SBH scanning electron microscope was used.

\section{Results and discussion}

The porosity of the sintered samples varies from $48 \%$ at $1350{ }^{\circ} \mathrm{C}$ down to $16 \%$ at $1650{ }^{\circ} \mathrm{C}$, which correlates well with the already existing data [12]. Fig. 1a shows the typical polished surface of the $\mathrm{Al}_{2} \mathrm{O}_{3}$ sample with $16 \%$ porosity. The grain size in the samples obtained at all sintering temperatures varies from 2 to 6 microns. At the same time, as the sintering temperature increases, the percentage of grains with a size of 4 to 6 microns increases. The pore sizes in the samples vary from 1 to 7 microns; for samples with a sintering temperature of $1350{ }^{\circ} \mathrm{C}$ and $1450^{\circ} \mathrm{C}$, the main pore size is from 1 to 4 microns, and for the highest temperatures the percentage of pores with a size of 4 to 7 microns increases, which coincides with the literature data [12-13]. The dependence of the porosity on the sintering temperature of the $\mathrm{Al}_{2} \mathrm{O}_{3}$ samples is shown in the Fig. $1 b$. As can be seen, the porosity of the samples decreases almost linearly with the increase of the sintering temperature, which corresponds with the literature data [13]. Extrapolation of this curve using $\log$ function to determine the temperature at which the porosity of the sample will smaller when $1 \%$ one obtained this temperature approximately equal $1850{ }^{\circ} \mathrm{C}$.
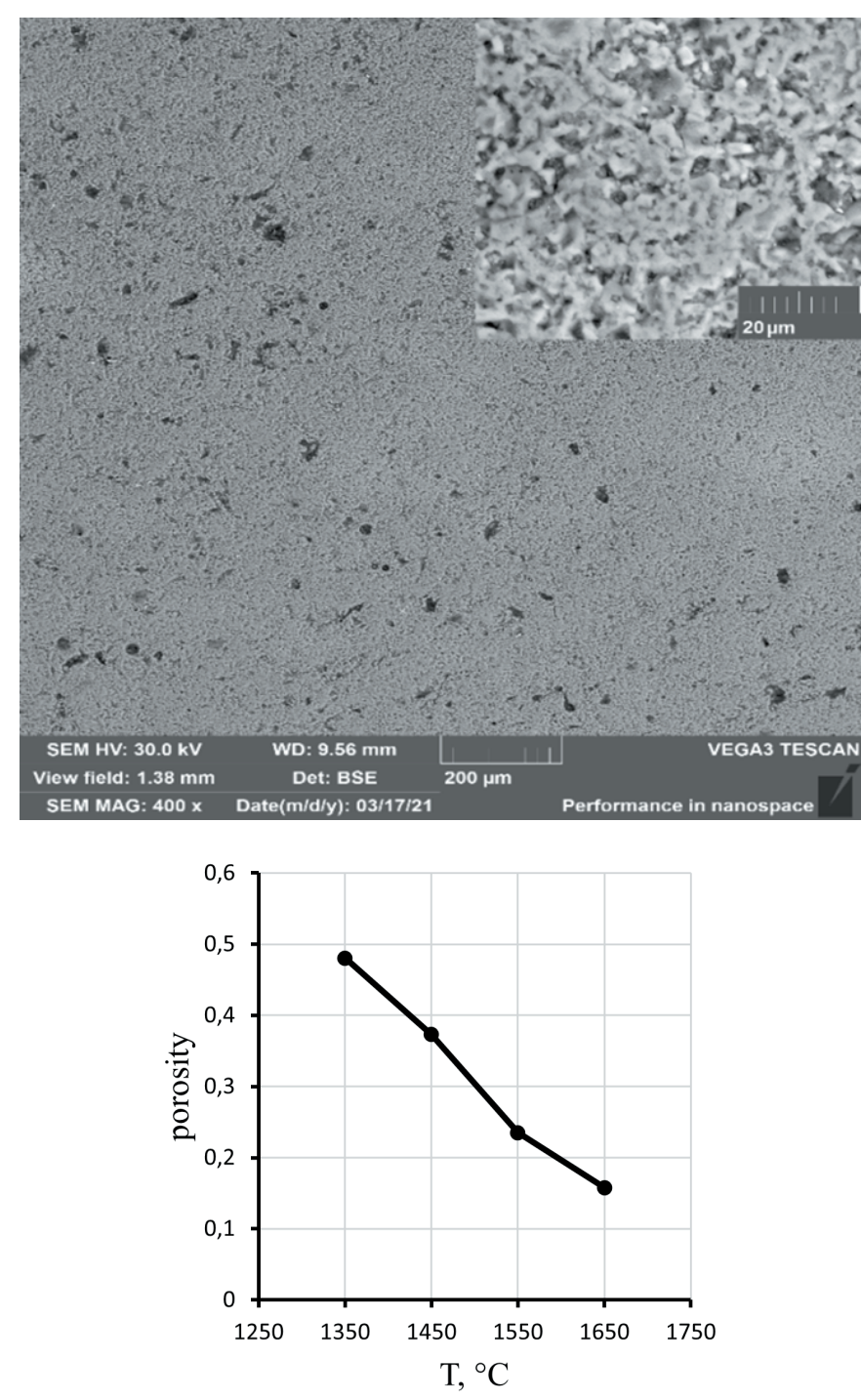

Fig. 1 Polished surface of the $\mathrm{Al}_{2} \mathrm{O}_{3}$ samples with 16\% porosity (a); Dependence of the porosity of the $\mathrm{Al}_{2} \mathrm{O}_{3}$ samples vs. sintering temperature (b).

1. ábra A 16\%-os porozitású $\mathrm{Al}_{2} \mathrm{O}_{3}$ minták csiszolt felülete (a); $\mathrm{Az} \mathrm{Al}_{2} \mathrm{O}_{3}$ minták porozitása a szinterelési hömérséklettöl függően (b).

The X-ray diffraction studies of the sample surfaces has shown, Fig. $2 a$, that the angles positions of diffraction peaks correspond to the rhombohedral structure of alumina and almost does not change with increasing temperature, which coincides with the literature data [14]. Only the width of X-ray lines had changed with increase of sintering temperature, therefore we have calculated the coherent diffraction domains sizes (CDD) for (012)-line with smallest angle diffraction, Fig. $2 b$, from which one can see that dependency of the coherent diffraction domains sizes for different sintering temperatures of the $\mathrm{Al}_{2} \mathrm{O}_{3}$ samples are increase with the increase of the sintering temperature and CDD changes from 450 angstroms at the lowest sintering temperature up to 610 angstroms at the highest temperature of $1650{ }^{\circ} \mathrm{C}$. On this figure a dash line is showing the initial powder's $\mathrm{CDD}$, which equals approximately to $400 \AA$, therefore extrapolation of this dependence on lower temperature had obtained that CDD changes after heating of the samples only after $1250^{\circ} \mathrm{C}$. 

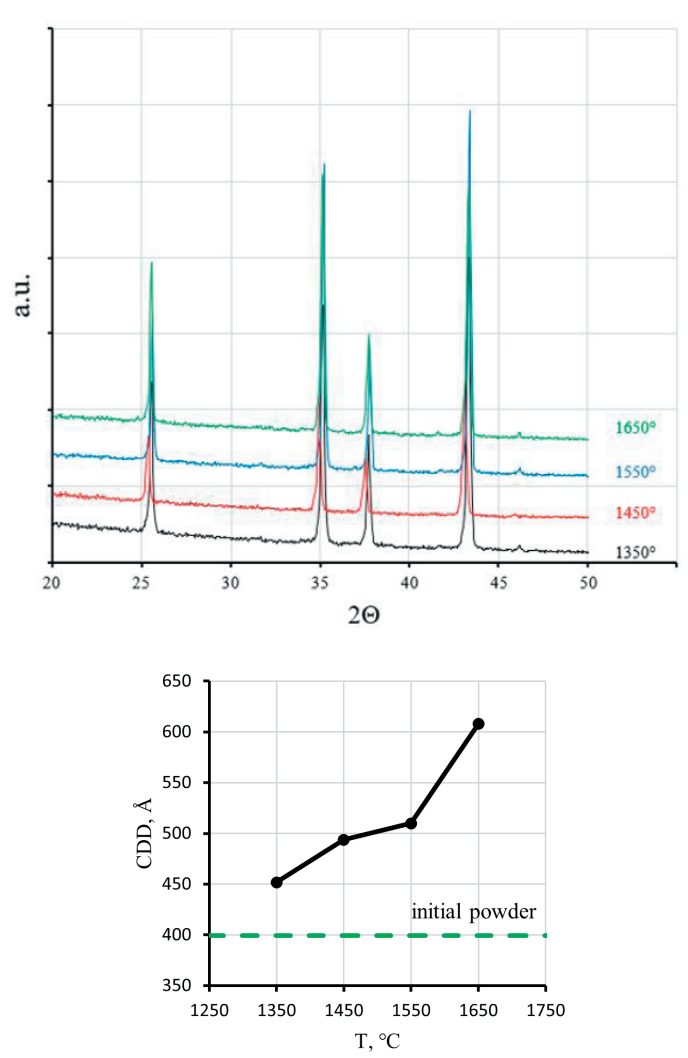

Fig. $2 \mathrm{X}$-ray diffraction patterns of the $\mathrm{Al}_{2} \mathrm{O}_{3}$ samples sintered at different temperatures (a); Dependence of the coherent diffraction domain (CDD) on the sintering temperature (b)

2. ábra Különbözö hömérsékleteken szinterelt $\mathrm{Al}_{2} \mathrm{O}_{3}$ minták röntgendiffrakciós mintázata (a); A koherens diffrakciós domén (CDD) mérete a szinterelési hőmérséklettöl függöen (b)

Fig. 3 shows the bending (a) and compressive (b) strengths of samples. The values of flexural strength vary between $8 \mathrm{MPa}$ at $1350^{\circ} \mathrm{C}$ and $87 \mathrm{MPa}$ at $1650^{\circ} \mathrm{C}$ with an almost linear increase and correlate with porosity of the samples (Fig. 1b). The correlation between the compressive strength and the sintering temperature of the alumina samples is shown in the Fig. $3 b$, the values are varied between 28 and $229 \mathrm{MPa}$. As one can see from these data the well-known correlation between the compressive and bending stresses occurs: compressive stresses exceed the bending stresses by 3 times.
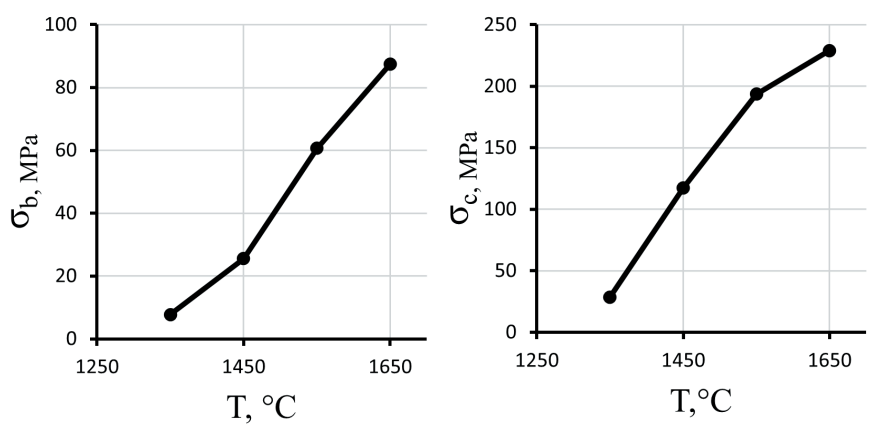

Fig. 3 Dependency of the bending (a) and compression strengths (b) vs. the sintering temperature

3. ábra A hajlitó (a) és a nyomószilárdságok (b) szinterelési hömérséklettől függően

A typical stress-strain curve during the uniaxial compression test is shown on the Fig. 4. The slope of curve in its linear part stipulates the technical Young's moduli of sintered samples, which is equal approximately $10.5 \mathrm{GPa}$. This modulus is rather small, probably due to a high porosity of sintered ceramics, but the samples sintered at the highest temperature and having the lowest porosity have the highest modulus of elasticity.

In this figure one can see some special region on stress-strain curve: small interruption of increasing stresses, marked with an arrow, which, as a rule, stipulate an internal micro-fault. This fact may be interpreted as due to the dilatancy effect when compressing the ceramic.

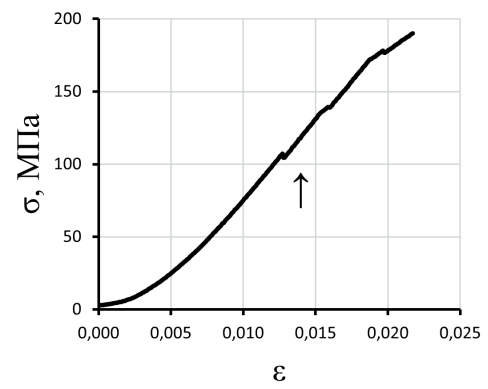

Fig. 4 Typical stress - strain curve for the uniaxially compressed $\mathrm{Al}_{2} \mathrm{O}_{3}$ samples; sintering temperature $1450^{\circ} \mathrm{C}$.

4. ábra $\mathrm{Az} 1450^{\circ} \mathrm{C}$-on szinterelt, egytengelyesen összenyomott $\mathrm{Al}_{2} \mathrm{O}_{3}$ minták tipikus feszültség - alakváltozás görbéje

In Fig. 5 the similar stress-strain dependence for the sample sintered at $1350{ }^{\circ} \mathrm{C}$ and the correlation between longitudinal - transverse strains measured during the compression test. The slopes of the linear approximations for the longitudinaltransverse strain curve will define the effective Poisson's ratio. At the initial stage of loading the effective Poisson's coefficient has a relatively good value 0.16 and correlate with table data, but at the strain of 0.0125 it sharply changes up to 1.6. This means that during the sample compression the appearance of an excess internal volume in the sample takes place even before the macrofracture effect, forming in internal parts of the sample [15]. These results clearly show the phenomenon of dilatancy, with a sharp increase of effective Poisson's ratio.

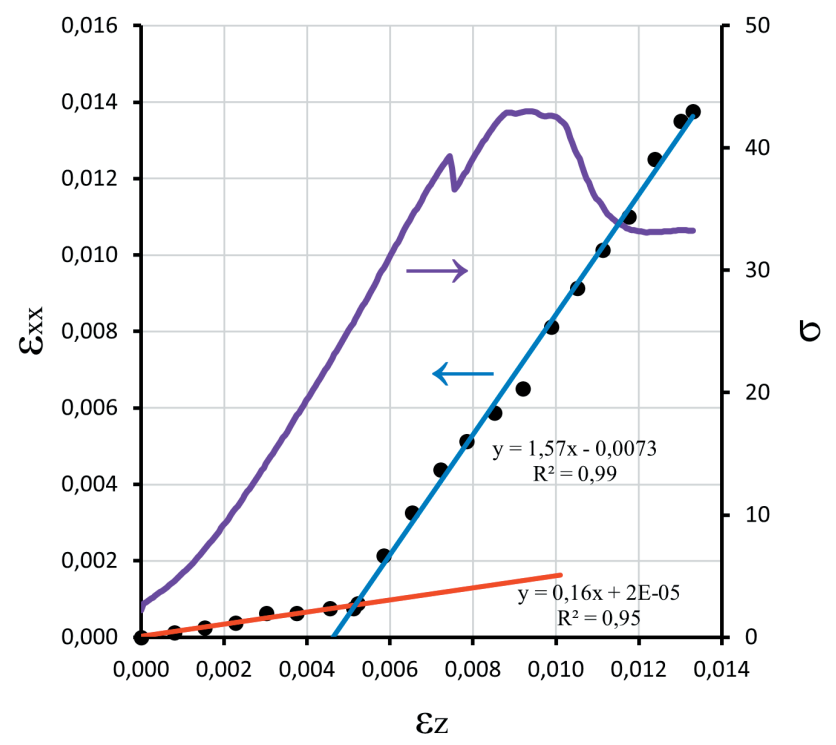

Fig. 5 Stress-strain curve and the corresponding "longitudinal - transverse" strains for sample sintered at $1350{ }^{\circ} \mathrm{C}$

5. ábra A feszültség-alakváltozás görbe és a megfelelo" „hosszirányú-keresztirányú” alakváltozás az $1350^{\circ} \mathrm{C}$-on szinterelt minták esetén 
Fig. $6 a$ shows the dependence of the change in the effective Poisson's ratio vs. density of the sintered samples. From the obtained $\Delta \boldsymbol{v}$ values one can see that an increase in strength and, accordingly, decrease in porosity significantly determines the changes of the Poisson's coefficient under loading, and this change begins long before the appearance of the first internal microcracks in the volume of the material, i.e., the appearance of excess volume. Therefore, the dilatancy can occur more easily with the increase in temperature. A similar pattern is observed in the analysis of CDD (Fig. 6b), i.e., with the growth of CDD, the formation of internal defects (microcracks) that cause the dilatancy effect can more easily occur in the material.
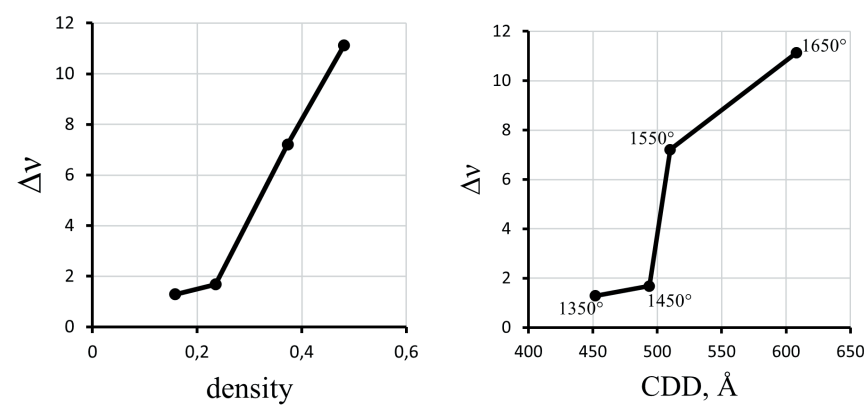

Fig. 6 Correlation between Poisson's ratio difference $(\Delta v)$ and density of the samples (a); Correlation between Poisson's ratio difference $(\Delta v)$ and coherent diffraction domain (CDD) (b).

6. ábra A Poisson-féle aránykülönbség ( $\Delta v)$ és a minták sürüsége közötti összefüggés (a); Korreláció Poisson-aránykülönbség $(\Delta v)$ és koherens diffrakciós domén (CDD) között (b).

\section{Conclusions}

It has been observed, that under uniaxial compression the transverse strain measuring allows a determination of Poisson's coefficient for ceramic samples under investigation.

It has been shown that an increase of strength and, accordingly, decrease in porosity are significantly determined the changes of the Poisson's ratio under loading, and this change begins long before the appearance of the first internal microcracks in the internal parts of the material, i.e., the appearance of excess volume. These results clearly show the phenomenon of dilatancy, with a sharp increase of effective Poisson's ratio.

\section{Acknowledgments}

The work was performed according to the Government research assignment for ISPMS SB RAS, project FWRW2021-0005. The described article was carried out as part of the EFOP-3.6.1-16-00011 "Younger and Renewing University -Innovative Knowledge City - institutional development of the University of Miskolc aiming at intelligent specialisation" project implemented in the framework of the Széchenyi 2020 program. The realization of this project is supported by the European Union, co-financed by the European Social Fund.

\section{References}

[1] Gömze, L.A., Kulkov, S.N., Kurovics, E. et al, (2018) Investigation of mineralogical composition and technological properties of conventional brick clays, Épitöanyag-JSBCM Vol. 70, No. 1. p.8 https://doi.org/10.14382/epitoanyag-jsbcm.2018.2

[2] Buzimov A.Y., Eckl W., Gömze L.A. et al, (2018) Effect of mechanical treatment on properties of Si-Al-O zeolites, Épitöanyag-JSBCM Vol. 70, No. 1. p.23. https://doi.org/10.14382/epitoanyag-jsbcm.2018.5

[3] Gnanavelbabu A., Sunu Surendran K.T., Kumar S., (2020) Influence of ultrasonication power on grain refinement, mechanical properties and wear behaviour of $\mathrm{AZ91D/nano-} \mathrm{Al}_{2} \mathrm{O}_{3}$ composites, Mater. Res. Express Vol.7 016544 https://doi.org/10.1088/2053-1591/ab64d7

[4] Gevorkyan E.S., Rucki M., Torosyan K.S., Kislitsa M.V. and Y Gutsalenko U.G., (2019) Composite materials based on fine-dispersed $\mathrm{Al}_{2} \mathrm{O}_{3}$ with enhanced physical and mechanical properties, J. Phys: Conf. Ser. Vol. 1347 012046 https://doi:10.1088/1742-6596/1347/1/012046

[5] Shirin Pourhosseini, Hossein Beygi and Seyyed Abdolkarim Sajjadi, (2018) Effect of metal coating of reinforcements on the microstructure and mechanical properties of $\mathrm{Al}_{-} \mathrm{Al}_{2} \mathrm{O}_{3}$ nanocomposites, J. Mater. Sci. Technol., Vol. 34, No. 2, 145-152 https://doi.org/10.1080/02670836.2017.1366708

[6] Zenkour, A.M., (2020) Quasi-3D Refined Theory for Functionally Graded Porous Plates: Displacements and Stresses, Phys. Mesomech., Vol. 23, No. 1 p.39 https://doi.org/10.1134/S1029959920010051

[7] Zenkour A.M., Radwan A.F. (2021) A Nonlocal Strain Gradient Theory for Porous Functionally Graded Curved Nanobeams under Different Boundary Conditions, Phys. Mesomech., Vol. 23, No. 6 p.601. https://doi.org/10.1134/s1029959920060168

[8] Azmah Hanim Mohamed Ariff, Mohamad Aznan Mohamad Najib , Suraya Mohd Tahir , Azizan As’Arry \& Norkhairunnisa Mazlan, (2020) Effect of sintering temperature on the properties of porous $\mathrm{Al}_{2} \mathrm{O}_{3}-10$ wt\% RHA/10 wt\% Al composite, Advances in Materials and Processing Technologies, https://doi.org/10.1080/2374068X.2020.1785204

[9] Cieślik J., (2014) Onset of Crack Initiation in Uniaxial and Triaxial Compression Tests of Dolomite Samples, Studia Geotech. et Mech. Vol. XXXVI, No. 1, p.23 https://doi.org/10.2478/sgem-2014-0003

[10] Diederichs M.S., (2007) The 2003 Canadian Geotechnical Colloquium: Mechanistic interpretation and practical application of damage and spalling prediction criteria for deep tunnelling, Can. Geotech. J., Vol.44, pp. 1082-1116 https://doi.org/10.1139/T07-033

[11] Nicksiar M., Martin C.D., (2012) Evaluation of Methods for Determining Crack Initiation in Compression Tests on Low-Porosity Rocks, Rock Mech. Rock Eng., Vol. 45, pp.607-617 https://doi.org/10.1007/s00603-012-0221-6

[12] Kulkov A.S., Smolin I.Yu., and Mikushina V.A., (2018) Investigation of mechanical response of $\mathrm{Al}_{2} \mathrm{O}_{3}$ ceramic specimens to loading with consideration for their structural features, AIP Conf. Proc. Vol. 2051, 020162 https://doi.org/10.1063/1.5083405

[13] Shengfang Shi, Sunghun Cho, Tomoyo Goto, Tohru Sekino, (2020) The effects of sintering temperature on mechanical and electrical properties of $\mathrm{Al}_{2} \mathrm{O}_{3} / \mathrm{Ti}$ composites, Mater. Today Commun. Vol. 25101522 https://doi.org/10.1016/j.mtcomm.2020.101522

[14] Momohjimoh I., Saheb N..Hussein M.A, Laoui T.,Al-Aqeeli N., (2020) Electrical conductivity of spark plasma sintered $\mathrm{Al}_{2} \mathrm{O}_{3}-\mathrm{SiC}$ and $\mathrm{Al}_{2} \mathrm{O}_{3}$ carbon nanotube nanocomposites, Ceram. Int. Vol. 46 pp. 16008-16019 https://doi.org/10.1016/j.ceramint.2020.03.151

[15] Cao, K., Khan, N., Liu, W. et al. (2021) Prediction Model of Dilatancy Stress Based on Brittle Rock: A Case Study of Sandstone, Arab J Sci Eng Vol. 46, pp. 2165-2176 https://doi.org/10.1007/s13369-020-05041-0

Ref.:

Kashin, A. D. - Kulkov, A. S. - Kulkov, S. N. - Kurovics, E. - Gömze, L. A.: Study of Transverse Deformation of Porous Alumina during Uniaxial Mechanical Tests

Építőanyag - Journal of Silicate Based and Composite Materials, Vol. 73, No. 4 (2021), 145-148. p. https://doi.org/10.14382/epitoanyag-jsbcm.2021.21 